\title{
INVESTIGATING THE NEXUS AMONG POVERTY ALLEVIATION, UNEMPLOYMENT, AND ECONOMIC DEVELOPMENT IN NIGERIA
}

\author{
(iD) Salam, Najeem \\ Gbadebo $^{1}$ \\ Alase, Gbenga \\ Ayofe $^{2}$ \\ D Lamidi, Sikiru \\ Olatunji ${ }^{3}$ \\ iD Tonuchi, \\ Emmanuel Joseph ${ }^{4+}$
}

\author{
${ }^{2.2 s}$ Department of Statistics, Central Bank of Nigeria, Abuja, Nigeria. \\ 'Email: gbadebosal@gmail.com \\ sEmail:alaseg@yahoo.com \\ 'Email: Lamidiso@gmail.com \\ ${ }^{4}$ Department of Statistics, Central Bank of Nigeria, Abuja; Department of $\quad$ (+ Corresponding author) \\ Economics, University of Nigeria, Nsukka, Nigeria. \\ EEmail:tonuchijoseph@gmail.com
}

Article History

Received: 17 February 2021 Revised: 22 March 2021 Accepted: 26 April 2021 Published: 24 May 2021

\section{Keywords}

ARDL

Economic development

Nigeria

Poverty

Poverty alleviation programmes unemployment.

JEL Classification: B22; D63; E24; I38; J6.

\begin{abstract}
The purpose of this study is to investigate the existing relationship between poverty alleviation programmes, unemployment, and economic development in Nigeria. Specifically, the study employed the Autoregressive Distributed Lag (ARDL) cointegration technique and Vector Autoregression (VAR) model to estimate the existing relationship between the variables, using time series data from the Central Bank of Nigeria $(\mathrm{CBN})$. The findings revealed that poverty alleviation programmes have a significant positive impact on economic development in Nigeria, while unemployment has a significant negative impact on economic development in Nigeria within the period under review. It was also revealed that poverty alleviation programmes granger causes economic development, but economic development does not granger cause poverty alleviation programmes as expected. However, unemployment and economic development granger cause each other as expected. The study, therefore, concludes that any policy aimed at addressing poverty and unemployment, if properly formulated and executed, will promote sustainable economic development in Nigeria.
\end{abstract}

Contribution/Originality: This study contributes to the first approach in determining whether economic development granger causes poverty alleviation programmes since it has been established in literature that poverty alleviation programmes are common in developing countries.

\section{INTRODUCTION}

Poverty and its antecedent consequences in society have been recognised in the economic literature since the day of Adam Smith when he argued that poverty is "the inability to purchase necessities required by nature or custom." Like every other definition, the necessities here entail basic things of life, such as clothing, shelter, food, basic education, and access to healthcare. The classical economist believes that poverty is mainly due to individual makings and systematic market failure to allocate resources efficiently and can be corrected through market incentives (Acemoglu \& Robinson, 2012), while the Keynesian believes poverty is involuntary mainly caused by unemployment (Tonuchi \& Onyebuchi, 2019).

Marxian believes poverty is mainly caused by class discrimination and can be solved through government policies such as minimum wage legislation, intervention programmes, among others. Capitalist (social exclusion) 
theory argues that there is a need for integration between the various schools on poverty by focusing on providing some kind of capital (including education) to aid the poor, anti-discriminatory laws, community development, and policies to offset adverse incentives and market failures that underlie poverty (Farina, 2015; Morazes \& Pintak, 2007). Aiyedogbon and Ohwofasa (2012) noted that poverty and unemployment are fundamental to Nigerian economic development, which is currently in a shambled state, following the country rank in the Human Development Index (HDI) as $158^{\text {th }}$ of 189 UN countries members in 2016 (UNDP, 2019). Tonuchi (2019) argued that poverty and unemployment are so interwoven and related that one can easily mistake one for the other. Taiwo and Agwu (2016) believe that not everyone unemployed is poor, and not everyone who is employed is free from poverty, especially the Nigerian situation where many working in the informal economy are underemployed (Joseph, Idowu, Adetoba, \& Mimiko, 2020).

Poverty and unemployment are not just an issue of developing countries such as Nigeria but rather a global issue that every government strives to eliminate from its domain (Ogbeide \& Agu, 2015). Given that the incidence of poverty mostly manifests in the form of mass unemployment, low aggregate demand, and high-income inequality, the government of Nigeria has developed several interesting policies aimed at poverty alleviation in the country (Gangas, 2017). Adelowokan, Maku, Babasanya, and Adesoye (2019) noted that there is a need for stable macroeconomic policies that would ensure equal distribution of income so that the poor also benefit from the country's growth (inclusive growth), thereby reducing poverty and increasing economic growth.

Unemployment in Nigeria was as low as 1.8 percent in the 1970 s but has over time risen to as high as 23.9 percent in 2011 and approximately 27.1 percent in 2018, comprising about 38 percent youth unemployment (Nigeria Bureau of Statistics, 2018). The situation was so bad that in 2014, the immigration service recruitment that is meant to fill 3,000 vacant positions attracted about 68,000 applications from youths, who turned in for an aptitude test. Unfortunately, eight of the applicants lost their lives in a stampede (Audrey, Carmel, Farmer, Morgan, \& Arlan, 2016). Similarly, of 20,000 applicants for the same job in Port-Harcourt, Nigeria, four people lost their lives in another stampede. Although Nigeria has witnessed impressive economic growth, especially from 2011 to 2014 (Nigeria Bureau of Statistics, 2018), this growth was not reflected in the economic development of the country, as the majority of the economic indicators have been deteriorating. Ibietan, Chidozie, and Ujara (2014) noted that Nigeria ironically was among the 50 richest countries in the world in the early 1970 s but has over time retrogressed to the rank of the 25 poorest countries in the world today. They noted that Nigeria houses the thirdlargest population living with poverty after China and India.

Another paradox and mind bugling situation is that despite the huge financial resources and policies targeted at the reduction of poverty in Nigeria and unemployment (from both international agencies such as UN, NGOs, and government of Nigeria), poverty and unemployment have remained the greatest threats to the common coexistence of the nation (Tonuchi \& Onyebuchi, 2019; UNDP, 2019). As analysed earlier, each government has introduced poverty alleviation programmes from time to time, but the situation has not shown any sign of improvement.

The incidence of poverty has generated serious social and insecurity issues in the country. Initially, it was an agitation from the Niger Delta region that set the pace for the destruction of the nation's resources, before the rise of the deadly Boko-Haram set, which has killed thousands of productive Nigerians, among others. Recently, agitations by secessionists emerged majorly in Southeast Nigeria, which is a sign of a failing system, which requires a comprehensive appraisal and re-structuring to develop a better measure of tackling the common problem facing the Nigerian economy (Tonuchi \& Onyebuchi, 2019; UNDP, 2019).

Specifically, the study is aimed at investigating the extent to which poverty alleviation programmes and unemployment enhance or hinder economic development in Nigeria, and whether there is a causal relationship between poverty alleviation, unemployment rate, and economic development in Nigeria. The remaining part of the research is organised into a literature review, methodology, analysis, and conclusion. 


\section{LITERATURE REVIEW}

\subsection{Poverty and Unemployment: an Overview}

It is very difficult to capture the concept of poverty by a single definition because poverty is not just a situation of life but also a state of mind and how an individual perceives self in the complex web of social relation (Ogbeide \& Agu, 2015; Taiwo \& Agwu, 2016). According to Bradshaw (2006), "poverty is the lack of necessities: food; shelter; medical care and safety that are generally thought to be necessary." The author's definition re-emphasised Adam Smith definition of poverty.

There are three major dimensions of poverty definition. The income (monetary) perspective of poverty definition views poverty or a poor person, that is as a person whose income is below the defined poverty level put at US $\$ 1.90$ or US $\$ 2$ per day. The second approach to defining poverty is where an individual lacks basic material for human sustainability, including lack of foods, comfortable shelter, access to healthcare, lack of education, lack of essential service, lack of sustainable employment, and participation. Lastly, poverty is also viewed as the lack of capacity both physically and mentally to live improved opportunities to achieve a minimally decent and comfortable life that affects their state of mind and reasoning (Tonuchi, 2019).

Poverty is experienced by the less privileged in society and observed by the most privileged in society. It manifests in different forms, such as 'lack of income and productive resources sufficient to ensure sustainable livelihood, poor welfare, mass unemployment, hunger and malnutrition, ill-health, limited or lack of access to education and other basic services, increased morbidity and mortality from illness, homelessness and inadequate, unsafe and degraded environment and social discrimination and exclusion.' A situation of lack of access to basic social amenities, including material wealth.

According to Tonuchi (2019), poverty can be absolute or relative, depending on the degree of survival of an individual. An absolute state of poverty is a state of total lack of basic human needs and necessity; it is a situation in which an individual economic condition is so bad that they rarely exist and have no hope of the next meal. Monetarily, it is a situation where an individual lives below US $\$ 1.50$ per day. However, relative poverty is a state where an individual gradually loses control of basic necessity and rarely survives with the available resources. This state is better than the absolute poverty level, and monetarily, they fall within the category of those who live below US $\$ 3.10$ per day in developing countries where the exchange rate is relatively low compared to developed countries with high exchange rates. Poverty can be measured using different approaches; the multidimensional poverty index (MPI) incorporates measures of health, education, and living standards (Morduch, 2005).

Factors that cause poverty include poor access to the goods and services market, poor education system leading to the poor state of mind, lack of access to employment opportunities, lack of physical capital and assets, poor human capital investment, and development. Others include poor implementation of poverty alleviation programmes, natural disasters such as 'pest, drought, floods, war, as well as poor and faulty economic foundation. Tonuchi (2019) identified the causes of poverty to include poor infrastructure development in the rural areas leading to rural-urban migration, poor economic development plan, poor attitude towards work, culture and heritage, corruption, and faulty institutional framework that encourage the mass accumulation of commonweal th by few privilege individuals. Taiwo and Agwu (2016) identified distortion in the labour market that introduces various forms of rigidities and criteria for accessing employment, discrimination along religion, ethnicity, sex, age, income inequality distribution, environmental degradation leading to loss of natural resources (oil spillage), poor economic management and policy discontinuity as leading causes of poverty in Nigeria.

Different authors have variously described unemployment in the like manner the poverty is done. For instance, the International Labor Organization (ILO) (2001) defined unemployment as 'a situation of being out of work or need of a job and continuously searching for it in the last four weeks. Unemployment literally means a situation where individuals who are capable of working and willing to work at the prevailing market wage rate could not find jobs for a period of more than one month. The classical economists believe that unemployment does 
not truly exist, and if it exists, it is short-lived. They therefore argue that unemployment can only occur through market interference. Their argument was criticized by Keynes, who argues that unemployment truly exists and is mostly caused by poor or low aggregate demand, often caused by poverty or low income (Tonuchi, 2019).

Unemployment is one of the greatest socioeconomic issues confronting Nigeria and most developing countries. There are millions of graduates produced every year, but the big question is "is there any employment opportunity for these graduates?". In Nigeria, unemployment has maintained a persistent rising trend over the decades, from 1.8 percent in the 1970 s to 38.5 percent in 2016. The unemployment rate in the country varies across the various age groups, educational levels, and sexes. According to the report of the National Bureau of Statistics (Nigeria Bureau of Statistics, 2018), approximately 17 percent of the labour force aged between 25-44 years is unemployed, and these trends have increased up to 47.8 percent in 2016 (Nigeria Bureau of Statistics, 2018); 14.8 percent and 21.3 percent were unemployed of those with primary and secondary education certificates, respectively. Some of the consequences of unemployment on individuals include anger, low self-esteem, unhappiness, mental disorder, depression, psychological trauma, frustration, brain stress, and poor standard of living, which often lead to criminal activities in society.

Unemployment has been variously classified to include frictional unemployment, seasonal unemployment, structural unemployment, and cyclical unemployment, among others. The danger of unemployment and poverty in an economy has caused various governments, international organizations, and NGOs to develop policies in tackling the menace. Gangas (2017) suggested that the government should put in place policies and measures that will enhance the turn-out of quality graduates with skills and competence to chart the course of development by all stakeholders in the education sector.

\subsection{Poverty and Unemployment Alleviation Policies in Nigeria (1970-2016)}

The Nigerian government and the NGOs in the country, in collaboration with various international organizations have, over time, developed various policies to address the poverty situation in the country. The policies were developed to increase the wellbeing of rural dwellers and reduce income inequality, among others. The first set of policies in the 1970s-1980s, best referred to as pre-SAP poverty alleviation policies, were basically focused on increasing farm products to increase aggregate consumption, raise income for rural dwellers and ensure food security in the country.

The pre-SAP poverty alleviation policies include the National Accelerated Food Production project (NAFPP), which was introduced in 1972, the Operation Feed the Nation of 1976, the Rural Banking Scheme of 1977, and the Green Revolution of 1980 .

The oil boom of the 1970 s led to the neglect of agriculture in the country with its antecedent challenges, which led to the introduction of some poverty alleviation programmes, such as the National Directorate of Employment (NDE), the Directorate for Foods, Roads and Rural Infrastructures (DFRRI) of 1986 and the Better Life Programme (BLP) of 1987 , to save the economy. These programmes were aimed at combating the mass unemployment, community development and social mobilization, community self-help projects, adult education, home economics, rural development, data collection and analysis, and the provision of rural housing and infrastructures and improving rural women development through skill acquisition and better healthcare access, among others.

At the beginning of civilian rule in 1999, poverty alleviation programmes were designed as an empowerment scheme. One of the core policies was targeted at poverty reduction, which led to the introduction of the National Poverty Eradication Programme (NAPEP). The NAPEP activities were grouped into four categories: Youth Empowerment Scheme (YES), Rural Infrastructure Development Scheme (RIDS), Social Welfare Service Scheme (SOWESS), and Natural Resources Development and Conservative Scheme (NRDCS). The National Policy on Integrated Rural Development (NPIRD) was introduced in 2003, mainly for developing rural areas. In 2004, the 
National Economic Empowerment and Development Strategy (NEEDS) was introduced mainly to cater for wealth creation, employment generation, poverty reduction, and value reorientation.

In 2012, the Subsidy Reinvestment and Empowerment Programme (SureP) was introduced to cover women and youth empowerment schemes, and its major aim was to reduce the effect of subsidy removal on women and youths and improve their wellbeing through job creation and entrepreneurship training. The SureP division includes the Graduate Internship Scheme (GIS) to assist unemployed graduates with jobs and YouWin to solve youth mass unemployment in the country. The programme generated up to 80,000-110,000 new jobs, provided business training for approximately 6,000 youths, and provided up to $\$ 10$ million equity grants for approximately 1,200 selected aspiring entrepreneurs to start their businesses.

Another major policy targeting at youth unemployment is the N-Power scheme that has engaged and trained over one million graduates. The programme classifies graduates into N-agro (focusing on developing youths in agriculture practice), N-Teach (focusing on training graduates in the teaching profession), and N-Health (training graduates on health management), among others. One of the criticisms of the programmes is that of poor implementation and poor recruitment of the participants. The programme failed to achieve its objective by training the various participants in the programme to become experts or near experts in their various chosen fields. Most of the participants rarely report to the place of assignments, and no measure to control such incidence. Few of the participants, who report to their places of primary assignments have not been properly engaged or assigned any task, which poses hindrance to the acquisition of relevant skills by the participants. Another issue with the programme is that majority of the respondents were selected randomly without proper scrutinisation to ensure their ability to learn and adapt to the training.

Other poverty alleviation programmes include the School Children Feeding programme, Payment of $\$ 5000$ to the most vulnerable Nigerians. The country also introduced YES-P, which is another recently launched programme, aimed at youth entrepreneurship and the development of small, medium-scale enterprises that can create jobs for teeming masses. The youth would initially be engaged in online training for six weeks, after which the successful candidates were invited for physical training on business management. One of the criticisms of the programme is the design and implementation of the programme (Tonuchi, 2019). The issue with the training, for instance, is that both the online and offline training were almost the same in content. Both were theory-oriented and have made no effort for practical training and assessment. The participants, though learn a lot of theories on managing businesses, have no practical experiences on how to go about certain basic requirements for successfully starting and funding a business. Tonuchi (2019) noted that while majority of them have been able to finish the training, approximately 85 percent of the participants are unable to secure loans for starting businesses due to lack of detail knowledge about the loan requirements, lack of basic requirements to secure the loan like collateral and many other challenges that the programme is designed to solve.

\subsection{Empirical Reviews}

The relationship between poverty, unemployment, and economic development has received little attention in the literature. The issue can be linked to several factors, including controversies surrounding the measure of economic development. Economic development is measured by income inequality, per capita income, and other variables. While some researchers find a positive relationship between unemployment and poverty (see (Acemoglu \& Robinson, 2012; Akinmulegun, 2014; Ogbeide \& Agu, 2015; Tonuchi, 2019)) other researchers argue that both unemployment and poverty granger cause each other, poverty reduces individual purchasing power, leading to a fall in aggregate demand, while unemployment leaves an individual with no income, making him vulnerable (Oduwole, 2015). Lastly, earlier research, such as that of Akinbobola and Saibu (2004) finds a negative relationship between unemployment, poverty, and economic development in Nigeria, noting that both unemployment and poverty tend to reduce the economic development of a nation. 
A recent study by Adelowokan et al. (2019) using error correction mechanism test found that there is no causal relationship between poverty, unemployment, and economic growth in Nigeria. It was further revealed that unemployment had a significant negative impact on economic growth in Nigeria. The authors further noted that the interaction between unemployment and poverty produced a significant positive impact on economic growth, contrary to theoretical expectation.

However, there are some noticeable shortcomings observed from some of the works reviewed so far, which necessitate the need for further studies. For instance, study by Adawo (2011) made use of survey techniques in gathering their data with its attendant weaknesses, among such are unsuitable for controversial issues, and that questions in surveys are always standardized before administering them to the subjects. Some of the works that employed econometric techniques in their analysis, such as Ogbeide and Agu (2015) and Akinmulegun (2014) among others who made use of ordinary least squares (OLS) and Granger causality tests, failed to conduct preliminary econometric tests, such as unit root tests, on the data to justify whether the data are stationary or not and, more so, the level of stationarity. The implication is that findings from such studies may not be reliable enough since there is a possibility that the data used for estimation is spurious. None of the studies reviewed made an effort to evaluate the relationship between the trio of economic development, unemployment, and poverty in Nigeria.

\section{RESEARCH METHODOLOGY}

This research uses both the autoregressive distributed lag (ARDL) approach and vector autoregressive approach (VAR) to examine the existing relationship among the variables in the model.

Wooldridge (2013) noted that "a distributed-lag model is a dynamic model in which the effect of a regressor $\mathrm{x}$ on y occurs over time rather than all at once". The general case for one explanatory variable and a linear relationship is as given below:

$$
y_{t}=\alpha+\beta(L) x_{t}+\mu_{t}=\alpha+\sum_{s=0}^{\infty} \beta_{s} x_{t-s}+\mu_{t}
$$

To determine the impact of poverty alleviation programmes and unemployment on Nigeria economic growth, equation two below is employed to capture the relationship.

The ARDL bound test model used in this model is expressed as follows:

$$
\begin{aligned}
& \Delta \ln P C I_{t}=\alpha_{0}+\sum_{i=1}^{n} \beta_{1} \Delta P C I_{t-i}+\sum_{i=1}^{n} \beta_{2} \Delta \ln R P C E S_{t-i}+\sum_{i=1}^{n} \beta_{3} \Delta \ln R P C I D_{t-i} \\
& +\sum_{i=1}^{n} \beta_{4} \Delta \ln D I N_{t-1}+\sum_{i=1}^{n} \beta_{5} \ln G C F_{t-i}+\varphi_{1}{\ln P C I_{t-1}}+\varphi_{2} \ln R P C E S_{t-1} \\
& +\varphi_{3} \ln R P C I D_{t-1}+\varphi_{4} \ln D I N_{t-1}+\varphi_{5} \ln G C F_{t-1}+\varepsilon_{\mathrm{t}}
\end{aligned}
$$

From Equation 2, PCI = real per capita income; RPCES = real per capita expenditure on social and community services; RPCID = real per capita expenditure on infrastructure development; UNMP = unemployment rate; and $\mathrm{CF}=$ capital formation; while $\boldsymbol{I n}$ represents the natural logarithm, $\Delta$ the first difference operator, and $\alpha_{0}$ the drift component. The expression with summation $\operatorname{sign}\left(\beta_{1}-\beta_{5}\right)$ represents the short-run dynamics of the model, while the coefficients $\left(\varphi_{1}-\varphi_{5}\right)$ represent the long-run relationship and $\varepsilon_{t}$ is the serially uncorrelated disturbance with zero mean and constant variance. 
The advantage of ARDL lies in its ability to be used when the time series are fractionally integrated, order one, and order zero. ARDL is also able to solve the problem of endogeneity often inherent in time-series data by including the lag of the dependent variable as an endogenous variable among the regressors. And lastly, it performs better with even a small sample size (Wooldridge, 2013).

To examine the causal relationship between the poverty alleviation programme, unemployment and economic development in Nigeria, the study follows the work of Gangas (2017). The model is thus specified as follows:

$$
\begin{gathered}
\text { PCI }_{t}=\alpha_{0}+\sum_{i=1}^{k} \alpha_{1 i} P C I_{t-i}+\sum_{i=1}^{k} \alpha_{2 i} \text { RPCES }_{t-i}+\sum_{i=1}^{k} \alpha_{3 i} U N M P_{t-i}+\varepsilon_{1 t} \\
\text { RPCES }_{t}=\beta_{0}+\sum_{i=1}^{k} \beta_{1 i} \text { RPCES }_{t-i}+\sum_{i=1}^{k} \beta_{2 i} P C I_{t-i}+\sum_{i=1}^{k} \beta_{3 i} U N M P_{t-i}+\varepsilon_{2 t} \\
U N M P_{t}=\varphi_{0}+\sum_{i=1}^{k} \varphi_{1 i} U N M P_{t-i}+\sum_{i=1}^{k} \varphi_{2 i} P C I_{t-i}+\sum_{i=1}^{k} \varphi_{3 i} \text { RPCES }_{t-i}+\varepsilon_{3 t}
\end{gathered}
$$

$\mathrm{k}$ denotes the optimal lag length, which is determined by the usual information criteria such as AIC and SIC.

All data are sourced from the Central Bank of Nigeria Statistical Bulletin and Nigeria Bureau of Statistics (NBS).

\section{RESEARCH ANALYSIS}

The model was first subjected to a unit root test to determine whether the model is free from unit-roots. This is predicated upon the assumption that the variable that is fit for regression must be stationary; otherwise, it will produce spurious results. Nonstationary data, in this case, will not be good for extrapolation because such variables have a long memory. The unit root test is presented in Table 1.

Table-1. Augmented dickey-fuller test (trend and intercept)

\begin{tabular}{c|c|c|c|c|c|c}
\hline Series & $\begin{array}{c}\text { ADF T- } \\
\text { Statistic } \\
\text { (LEVEL) }\end{array}$ & $\begin{array}{c}\mathbf{5 \%} \text { critical } \\
\text { values }\end{array}$ & $\begin{array}{c}\text { ADF T- } \\
\text { Statistic } \\
\text { (1ST DIFF) }\end{array}$ & $\begin{array}{c}\mathbf{5 \% c r i t i c a l} \\
\text { values }\end{array}$ & $\begin{array}{c}\text { Order of } \\
\text { Integration }\end{array}$ & Remarks \\
\hline LNPCI & -2.535060 & -3.557759 & -6.295791 & -3.548490 & $1(1)$ & Stationary \\
\hline LNRPCES & -0.272777 & -3.562882 & -7.687933 & -3.548490 & $1(1)$ & Stationary \\
\hline LNRPCID & -4.020798 & -3.548490 & - & - & $1(0)$ & Stationary \\
\hline LNUNMP & -3.548490 & -3.548490 & - & - & $1(0)$ & Stationary \\
\hline LNGCF & -3.302976 & -3.557759 & -4.997109 & -3.552973 & $1(1)$ & Stationary \\
\hline UNMP & -1.036867 & -3.544284 & -5.002147 & -3.548490 & $1(1)$ & Stationary \\
\hline
\end{tabular}

Table 1 above revealed that both real per capita expenditure on infrastructure development (RPCID) and the unemployment rate were stationary at level since their (ADF) test statistics were greater than their critical values in absolute value while other variables (PCI, RPCES, GCF, and UNMP) were nonstationary since their Augmented Dickey-Fuller (ADF) test statistics were greater than their critical values in absolute value. However, it was revealed that after the first difference of the variables, all the remaining variables became stationary. Thus, the variables were fractionally stationery either at a level or at the first difference, which prompted the application of ARDL to estimate the relationship.

Pesaran, Shin, and Smith (1999) suggested that when time series are fractionally integrated, particularly of order one and order zero, the first step in estimating the equation using the ARDL approach is to estimate the 
standard ARDL regression followed by post estimation test like Cusum stability test and Breuch Godfrey to ensure that the estimated regression is not autocorrelated and ensures a test of model stability. The serial correlation test following the standard ARDL test is presented in Table 2:

Table-2. Breusch-Godfrey Serial Correlation LM Test.

\begin{tabular}{c|c|c|c}
\hline F-statistic & 2.9863 & Prob. F $(2,7)$ & 0.1154 \\
\hline Obs*R-squared & 4.2726 & Prob. Chi-Square $(2)$ & 0.2843 \\
\hline
\end{tabular}

The test revealed that F-statistics is 2.986, while its p-value is 0.1154 . Since the P-value is greater than 5 percent (0.05), the study, therefore, rejects the null hypothesis that there is serial correlation and concludes that the model is free from serial correlation. The CUSUM test was also conducted to validate the stability of the model, as presented in Figure 1 below. As revealed, the blue line is bounded by the two red lines, an indication that the model is stable over time and valid for estimation of the relationship.

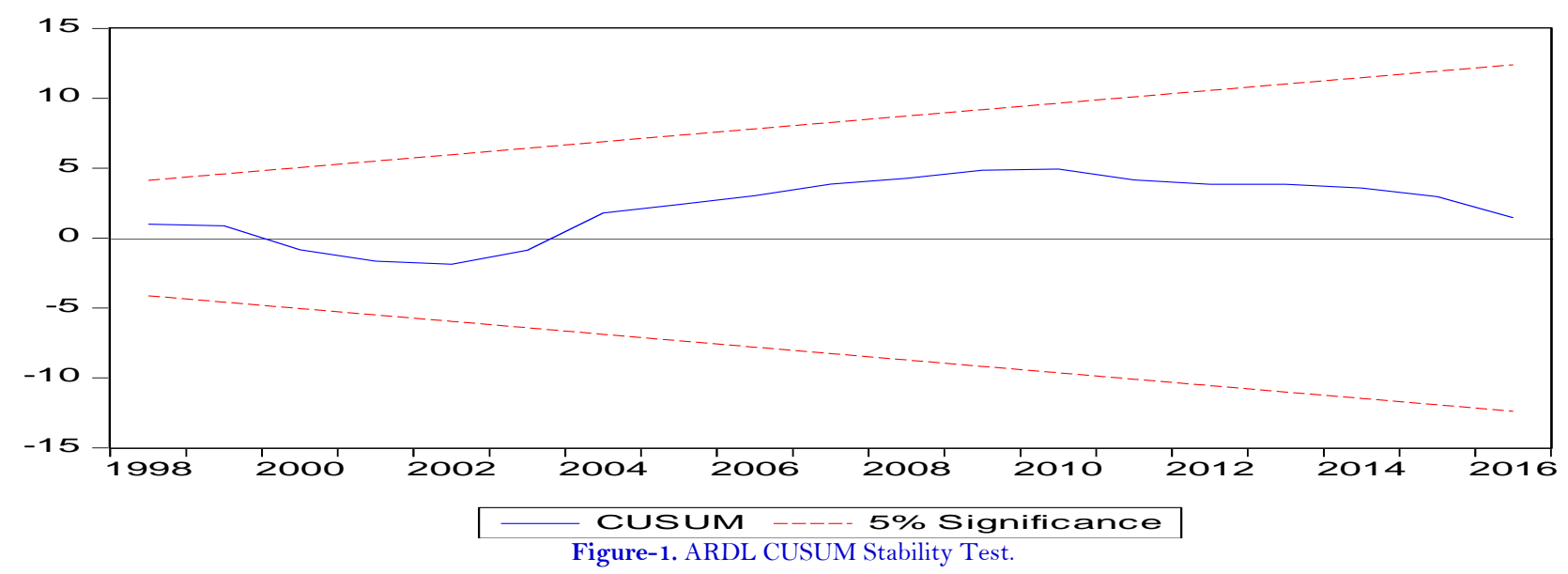

Given that the time series are fractionally integrated of order zero and one, the study made further effort to estimate the bound test to establish the existence of long-run relationships among the time series as presented in Table 3 below.

Table-3. Bounds Test Estimate.

\begin{tabular}{c|c|c|c|c}
\hline \multicolumn{5}{c}{ Null Hypothesis: No long-run relationships exist } \\
\hline Test Statistic & Value & K & & \\
\hline F-statistic & 6.178107 & 4 & & \\
\hline
\end{tabular}

The study rejects the null hypothesis of no long-run relationship, given that the F-test (6.178107) is greater than the upper critical bounds value (4.01). This implies that there exists a long-run relationship between the time series. Having ascertained the existence of time series, the study proceeds to estimate the long-run relationship as presented.

The findings as in Table 4 revealed that government expenditure on social and community service (a proxy for poverty alleviation programmes, LNRPCES) is positively correlated with real per capita income. Particularly, both unemployment and measure of poverty alleviation programmes have a significant impact on economic development in Nigeria. For instance, a one percent rise in poverty alleviation programmes will increase economic development by, at least, three percent while a percent rise in unemployment will decrease economic development by 6 percent. Both capital formation and real capita expenditure on infrastructure are not significant at five percent, even though they are both rightly signed. 
Table-4. Long Run Estimate.

\begin{tabular}{l|c|c|c|c|c}
\hline \multicolumn{7}{l|}{ Dependent Variable: LNPCI } & & \\
\hline Variable & Coefficient & Std. Error & t-Statistic & Prob. & Remarks \\
\hline C & -1.746165 & 3.265038 & -0.534807 & 0.5969 & Not significant \\
\hline LNPCI(-1) & 0.802017 & 0.121026 & 6.626827 & 0.0000 & Significant \\
\hline LNRPCES(-1) & 0.034643 & 0.021035 & 16.46922 & 0.0000 & Significant \\
\hline LNRPCID(-1) & 0.042531 & 0.055207 & 0.770390 & 0.4473 & Not significant \\
\hline LNGCF(-1) & 0.117723 & 0.163707 & 0.719108 & 0.4778 & Not significant \\
\hline LNUNMP(-1) & -0.065001 & 0.025662 & -2.532967 & 0.0053 & Significant \\
\hline R-squared & 0.947651 & Durbin-Watson stat & 2.216616 & \\
\hline Prob(F-statistic) & 0.000000 & & & & \\
\hline
\end{tabular}

This implies that an increase in government concerted efforts to increase government spending on poverty alleviation will improve the state of wellbeing of the masses captured by the per capita income. This is consistent with the economic development theory. More spending on poverty alleviation will raise per capita income, thereby inducing the aggregate demand in the country and ultimately lead to increased general wellbeing. The finding is in line with the findings of other researchers such as Aiyedogbon and Ohwofasa (2012) that discovered that poverty alleviation programmes improve the living standard of the masses through increasing their purchasing power, as a result of more disposable income.

The second model that examines the causal relationship between poverty alleviation, unemployment, and economic development in Nigeria is captured in Table 5.

Table-5. Granger causality test.

\begin{tabular}{l|c|c|c}
\hline \multicolumn{2}{l|}{ Lags: 2} & & \\
\hline Null Hypothesis: & Obs & F-Statistic & Prob. \\
\hline LnRPCES does not Granger Cause LnPCI & 34 & 9.42709 & 0.0007 \\
\hline LnPCI does not Granger Cause LnRPCES & & 0.58536 & 0.5634 \\
\hline UNMP does not Granger Cause LnPCI & 34 & 3.70778 & 0.0368 \\
\hline LnPCI does not Granger Cause UNMP & 34 & 12.5377 & 0.0005 \\
\hline UNMP does not Granger Cause LnRPCES & & 0.63285 & 0.7196 \\
\hline LnRPCES does not Granger Cause UNMP & & 0.5212 \\
\hline
\end{tabular}

The study reveals that there is unidirectional causality between social and economic expenditure (poverty alleviation programmes) where social and economic expenditure granger causes economic development. This implies that policies of poverty alleviation will induce economic development, but economic development measure does not induce poverty alleviation. The finding is well expected as a developed economy will likely spend less on poverty alleviation. Unemployment and a measure of economic development, on the other hand, have a bidirectional relationship as unemployment granger causes economic development at a five percent level, and economic development also granger causes the unemployment rate in any country. Theoretically, both variables are expected to granger causes each other.

The finding is contrary to the findings of Adelowokan et al. (2019), who argued that there was no established causal relationship between poverty, unemployment, and economic growth. The possible reason might be their use of gross domestic product (GDP) to capture economic growth, whereas this study uses per capita income (PCI) to capture economic development.

\section{CONCLUSION}

The study investigated the relationship between poverty alleviation programs, unemployment, and economic development in Nigeria. The time-series data were subjected first to the unit root test using the Augmented Dickey-Fuller test (ADF). It was revealed that the series is fractionally integrated of both order zero and order one. The ARDL test revealed further that poverty alleviation programmes have a positive significant impact on 
economic development in Nigeria, while unemployment has a significant negative impact on economic development in Nigeria.

The result is consistent with most of the empirical literature reviewed earlier. The results of the discussions also revealed that there is a unidirectional relationship between economic development and poverty alleviation programmes in Nigeria, while a bidirectional relationship exists between unemployment and economic development in the country, contrary to the findings of Adelowokan et al. (2019).

The study thus concludes that unemployment, poverty alleviation, and economic development have a causal relationship between and among each other. Particularly, the study revealed that unemployment has a negative long-run relationship with economic development, while poverty alleviation has a significant positive impact on economic development. This study implies that government policies aimed at improving the wellbeing of the masses in terms of poverty alleviation and employment creation have been effective in achieving improved economic development in Nigeria. The study recommends, among others, that government should increase programmes on poverty alleviation, especially those targeting youth unemployment, but such programmes should involve wider consultation of stakeholders, including the target audience, to ensure a complete acceptance and participation in the programmes.

Funding: This study received no specific financial support.

Competing Interests: The authors declare that they have no competing interests.

Acknowledgement: All authors contributed equally to the conception and design of the study.

\section{REFERENCES}

Acemoglu, D., \& Robinson, J. A. (2012). Why nations fail: The origins of power, prosperity and poverty. New York: Crown Business.

Adawo, M. (2011). Poverty reduction in Nigeria: A necessary agenda. Current Research Journal of Economic Theory, 3(1), 14-19.

Adelowokan, O. A., Maku, O. E., Babasanya, A. O., \& Adesoye, A. B. (2019). Unemployment, poverty and economic growth in Nigeria. Journal of Economics and Management, 35(1), 4-17.

Aiyedogbon, J. O., \& Ohwofasa, B. O. (2012). Poverty and youth unemployment in Nigeria. International Journal of Business and Social Science, 3(20), 269-274.

Akinbobola, T. O., \& Saibu, O. O. (2004). Income inequality, unemployment, and poverty in Nigeria: A vector autoregressive approach. The Journal of Policy Reforms, 7(3), 23-28.

Akinmulegun, S. (2014). Unemployment and poverty paradigm in Nigeria: Challenges and prospect. International Journal of Management and Administrative Sciences, 2(3), 16-23.

Audrey, R. C., Carmel, W., Farmer, P., Morgan, S., \& Arlan, F. (2016). Expenditure on health and poverty reduction. Health and Human Rights Journal, 18(2), 1-14.

Bradshaw, T. K. (2006). Theories of poverty and anti-poverty programs in community development. Rural Poverty Research Center, RPRC Working Paper No. 06-05, February. RUPRI Rural Poverty Research Center 214 Middlebush Hall University of Missouri Columbia MO 65211-6200 PH 573.

Farina, F. (2015). Development theory and poverty. A review. Italian Association for the Study of Comparative Economic Systems Discussion Paper 5, 1-24. Retrieved from: http://www.aisseccomparativestudiesassociation.org/AISSEC_DP_2015_5.pdf.

Gangas, S. (2017). Relationship between economic growth and poverty reduction in Nigeria. Pyrex Journal of Business and Finance Management Research, 3(2), 34-56.

Ibietan, J., Chidozie, F., \& Ujara, E. (2014). Poverty alleviation and the efficacy of development assistance models in Nigeria: An appraisal. International Journal of Humanities Social Sciences and Education, 1(4), 1-8.

International Labor Organization (ILO). (2001). Total unemployment. Retrieved from: https://www.ilo.org/wcmsp5/groups/public/_--dgreports/_--stat/documents/publication/wcms_422438.pdf. 
The Economics and Finance Letters, 2021, 8(2): 190-200

Joseph, E. T., Idowu, P., Adetoba, O. O., \& Mimiko, D. O. (2020). How large is the size of Nigeria's informal economy? A MIMIC approach. International Journal of Economics, Commerce, and management, 8(7), 204-227.

Morazes, J., \& Pintak, I. (2007). Theories of global poverty: Comparing developed world and developing world frameworks. Journal of Human Behavior in the Social Environment, 16(1-2), 105-121. Available at: https://doi.org/10.1300/j137v16no1_08.

Morduch, J. (2005). Poverty measures. In United Nations Statistics Division (Ed.), Handbook on Poverty Statistics: Concepts Methods and Policy Use (pp. 52-84).

Nigeria Bureau of Statistics. (2018). Labour force statistics Volume I: Unemployment and Underemployment Report. Retrieved from: https://www.nigerianstat.gov.ng/pdfuploads/Q2_2020_Unemployment_Report.pdf.

Oduwole, J. N. (2015). Youth unemployment and poverty in Nigeria. International Journal of Sociology and Anthropology Research, 1(2), 23-39.

Ogbeide, E. N., \& Agu, D. O. (2015). Poverty and income inequality in Nigeria: Any causality? Asian Economic and Financial Review, 5(3), 439-452. Available at: https://doi.org/10.18488/journal.aefr/2015.5.3/102.3.439.452

Pesaran, M. H., Shin, Y., \& Smith, R. P. (1999). Pooled mean group estimation of dynamic heterogeneous panels. Journal of the American Statistical Association, 94(446), 62 1-634. Available at: https://doi.org/10.1080/0162 1459.1999.10474156.

Taiwo, J. N., \& Agwu, M. E. (2016). Problems and prospects of poverty alleviation programmes in Nigeria. International Journal of Business and Management Review, 4(6), 18-30.

Tonuchi, J. E., \& Onyebuchi, N. A. (2019). Economic diversification in Nigeria: The role of agriculture and manufacturing sec tor. International Journal of Research in Electronics and Computer Engineering, 7(3), 916-919.

Tonuchi, J., E. (2019). An appraisal of pverty alleviation programmes in Nigeria. Paper presented at the Nokolite Economic Policy Discussion September, 16-18.

UNDP. (2019). Inequalities in human development in the 21 st century briefing note for countries on the 2019 human development Report. Human Development Report.

Wooldridge, J. (2013). Econometric analysis of cross section and panel data. Cambridge, MA: MIT Press.

Views and opinions expressed in this article are the views and opinions of the author(s), The Economics and Finance Letters shall not be responsible or answerable for any loss, damage or liability etc. caused in relation to/arising out of the use of the content. 